\title{
editorial
}

\section{1 negotiating new terrains: South Asian feminisms}

The 'Woman Question' has been central to the nation-making process in South Asia. Through the mid-nineteenth to early twentieth centuries, it was on the terrain of the 'status of women', designated as the symbol of the 'progressiveness' or 'backwardness' of a society, that debates on tradition and modernity were played out between male elites and colonial powers (Kumar, 1993: Chapter 2; Mani, 1989; de Alwis, 2002). ${ }^{1}$ Women became the index of the suitability or otherwise of colonies for self-government. On the other hand, traditionalist male elites asserted their anti-imperialism precisely through withdrawing from such debate, claiming that national autonomy depended on preserving the realm of tradition from western colonial intervention. Middle-class women's participation in these debates was also intense and engaged, but from the perspective of the mainstream

1 We do not attempt a complete bibliography here of course, the references are merely indicative of research in the field. male discourse, marginal to its outcome.

However, simultaneously, the fact of women's active participation in anti-colonial movements resulted in the idea of national liberation being thoroughly imbued with notions of women's rights and freedoms (Jayawardena, 1986).

This legacy has been carried over into the decades since independence, in which the various social movements that have emerged in the region have had to grapple with issues of gender equality, violence against women, women's social positioning and so on; these questions arising either through the interventions of very lively autonomous women's movements, or because of internal feminist pressures within these movements.

Post-colonial South Asia has been marked by internal dissensions and power struggles. Freedom from British colonialism had been accompanied by partition, creating new borders between India and the newly formed state of Pakistan. Moreover, geographical division between the two wings of Pakistan was accompanied by differences in language, which soon evolved into a struggle for a different nationality. Formed on the basis of a commonality of religious identity, the two wings followed different trajectories after 1947, and the eastern wing soon felt that a new form of colonialism was being exercised over it. Differences of language and culture, and the issue of economic exploitation surfaced, which led to a 'second' liberation struggle 
and the emergence of the state of Bangladesh in 1971. Women again emerged as symbolic in this struggle, and this time the struggle was between defining the 'Bengali' woman as opposed to the 'Muslim' woman. While Bangladesh still struggles to define its political and cultural identity, the women of the nation have had to forge their own struggle with issues of identity and nationhood. Feminist historians have pointed out to the very complex positioning that women occupy, especially when we consider victims of war rape, and women of ethnic, religious and linguistic minorities (Mohsin, 1997; Ibrahim, 1998).

These decades have also seen the continued pitting against each other of discourses of 'modernity' and 'tradition'. Much as in the colonial period, for one kind of discourse, women are designated as the markers of progress from tradition to modernity, while for another, women are the space of nationalist assertion against globalizing 'western' (especially American) capitalism (Khan et al., 1994; Hussain et al., 1997; de Alwis and Jayawardena, 1998).

This special volume of Feminist Review emerged out of a desire to look at where feminist thinking and activism in South Asia stand today. Conceptualizing South Asia as a region is in itself a complex task. We have chosen to remain within the framework set by current national borders but this is of course, only one way of engaging with the region. These borders are colonial constructions for the most part, and 'South' Asia has long histories of trade and cultural interchange with North Africa, West Asia and China. The borders of the nation-states of South Asia are porous for the thousands of people crossing them everyday, illegally for the most part, in search of work or safety. These borders are also crossed in daily ubiquitous ways, not as conscious gestures, or in a grand and crisis-laden move, but because many human activities - animal herding, cultivation - simply do not adjust to modern national boundaries.

Recent work on women and migration in Asia addresses one aspect of this interconnectedness (Siddiqui, 2003; Thapan, 2005; Arya, 2006; Behera, 2006; Agrawal, 2006; Palriwala, 2008). Naila Kabeer's work on Bangladeshi women garment workers, tracing their lives in Dhaka and London addresses another aspect of gender and culture in the contemporary global economy (2000). However, there is much room for feminist scholarship on South Asia that looks at cross-border politics and trends within the region.

The other aspect of writing on 'South Asia' is that the perspective changes depending on location. For us situated in Bangladesh or India, anti-colonial struggles and post-colonial nation-making seem to be the point of departure. This trajectory, however, has very little resonance for feminists in Nepal. The partition of the subcontinent in 1947 has enormous significance for India, Pakistan and to a lesser extent, Bangladesh (Menon and Bhasin, 1998; Butalia, 2000; Bagchi and Dasgupta, 2003), but Sri Lanka and Nepal have other histories of national and ethnic divisions to deal with (Jeganathan and Ismail, 1995; 
Thapa, 2005; de Mel, 2007). Bangladesh, as noted earlier, has its own trajectory of post-partition history. It is interesting how this history has often been used to build bridges with feminists in Pakistan, in an effort to write other stories.

Religion as a factor in national identity speaks differently in different countries. And within the countries themselves, political struggles are inflected by local dimensions, whether of class, religious or caste identities, regional aspirations within nation-states and so on. In addition, relationships among these nationstates are unequal and contested; they are further complicated by geopolitical developments and the differential effects of globalization and imperialist expansion on each country. It is within this variegated terrain that feminist struggles and concepts have shaped themselves and engaged with various formations of power.

South Asia, and hence South Asian feminisms, cannot be held within an easily identifiable or singular framework, but nevertheless there are enough characteristics in common to justify a volume that looks at feminist activism and thinking in the region.

What singularly marks this region for us is the sheer presence of feminist activism throughout the past century. Of course we can go back further in time historically; but even if we just concentrate on the latter half of the twentieth century, the energy and the volume of work that has marked women's activism is notable. Feminist activism has engaged with religious fundamentalisms, state repression, sexual violence and livelihood issues, while women have been visibly active in all the political movements in this volatile region.

This issue of Feminist Review seeks to look at what is new and what has changed in the arena of feminist activism and thinking.

The first three essays are centred on women, feminism and religion, both politicized religion and religion as faith.

A striking development in the region has been the resurgence of religion-based political mobilization, which is the focus of the first two articles in this collection. The gendered aspects of political Islam in South Asia are of interest not only to feminist activists in the region but also elsewhere, primarily because of the anxieties generated by the 'war on terror'. In this regard, Amina Jamal looks at Islamic activism and its address to women, pointing perhaps to a new kind of feminist activism in the making. The experience of the Pakistani women's movement raises familiar questions and dilemmas for feminism arising from the phenomenon of politically active women in the religious right. Afiya Shehrbano Zia's contribution outlines how the women's movement in Pakistan reformulated its avowedly secular (non-religious) position in order to engage with the large numbers of militant women in religion-based politics in the country. The third essay moves on to look at how women are engaging with religious traditions in 
other ways. While the supposed dichotomy between tradition and modernity is continuously produced in the field of politics, Ruth Vanita's study of lesbian marriages in India shows us how the supposedly modern notion of same-sex love can sit quite comfortably with Hindu traditions.

The next three essays are on feminist politics as located within other trends in the region. Seira Tamang looks at women in the Maoist movement in Nepal, examining the way in which feminist issues are included (or not) within this movement, while Malathi de Alwis talks about women in the peace movement in Sri Lanka, and the way in which the maternal role is made to take on a new political dimension. Nivedita Menon's contribution addresses the contested meanings of 'gender' in India as they emerge between feminist politics and the governmentalizing drive of the Indian state.

Two contributions deal specifically with women and political organization in India. Manuela Ciotti looks at the much-lauded reservations at the panchayat level, and examines the factors that have enabled the entry of large numbers of women into electoral politics. The article concentrates on the state of Uttar Pradesh and women members of the Dalit 'Bahujan Samaj Party', and argues that family approval, specifically that of the husband, is an important impetus for women's entry into the political sphere. (In this context it might be interesting to consider Sharmila Rege's Writing Caste/Writing Gender: Narrating Dalit Women's Testimonios in which she presents Dalit women's testimonies to challenge the prevailing communitarian notion of a singular Dalit community; Rege, 2006.) In the second paper here, Srila Roy talks about the complex relationship between women and violence-based struggles. While there is feminist scholarship on violence on women (Kannabiran, 2005), and scholars have examined the troubling and often violent presence of women in right-wing organizations (Sarkar and Butalia, 1995), this article looks at women's participation in left-wing popular movements, thus raising a more troubling question for feminism, and puts the ethics of violence in political struggles through a fresh examination.

The final article addresses the question of changes in women's positioning in the workforce. Such changes call for a different negotiation between the private and the public, especially as women enter the workforce in greater numbers. Dina Siddiqi's article looks at the ways in which the sexual harassment of women in the ready-made garment-manufacturing sector in Bangladesh and the sexualised delineation of women workers are elided by a developmental discourse that valorizes these women as 'national treasures' - valued contributors to the national economy. As women slip through the borders of traditional patriarchal controls, new forms of patriarchal control emerge and the negotiations between the spaces that women traverse have to be fashioned accordingly.

The inclusion of short stories and poems from the South Asian region will, it is hoped, bring in a fresh dimension to looking at feminist issues. Creative writing, 
especially in this age of technological media, continues to provide women with an autonomous sphere of expression, where thoughts and ideas are presented and debated. Despite this, literature has provided at best a contested area, where questions of literature as social reflection and/or a sphere for the creation of utopias and other worlds have been debated. In the case of women's writing, the issue of gender difference has been the point of departure and the notion of a woman's language, as different from that of a man's, or a separate literary tradition, has been posed and contested. Interestingly, in the South Asian region, women's place in literature has not been debated as merely gender difference, but has been tied in with the issues of post-coloniality, and especially of postcolonial nation-making. In this context, the anthology Women Writing in India: 600 B.C. to the present (Tharu and Lalitha, 1993) is perhaps the most significant intervention. This voluminous and comprehensive anthology points to the problematic positioning of women within the national sphere in various ages. It eschews a simple progressive narrative - one where women gradually 'progress' to taking their 'rightful' position and directs us instead to the complex placement that women occupy in political and cultural life. Differences in women's position can be used to bring out differences in class and community positions as well. This is the ground that is covered in an anthology such as Zenana Mahfil, (Stree, Kolkata, 1998 and English translation (Stree, Kolkata, 2008) Women in Concert: An Anthology of Bengali Muslim Women Writing 1904-1938) which is an anthology of Muslim women's writing in Bengal during the first half of the twentieth century. This anthology boldly foregrounds the different trajectories that Hindus and Muslims followed in their quest for post-colonial nationhood in the region, and the placement of women within the Muslim narrative. Much as the anthology has been noted for the highlighting of communal difference, it is, on the other hand, a wonderful record of commonality as well as difference, and provides a nuanced reading of women's participation in, and placement within, emerging national identities in Bengal. Another anthology - Shaheen Akhtar's Sati 0 Santantara (Good and Independent Women, Dibya Prakash, Dhaka, 2007) - highlights another difference in the way that women's writing is placed. This three-volume anthology of women's writing in Bengal traces the 'folk' and 'formal' structures of literature, belying the charge that writing is a middle-class activity, and thus reflects middle-class issues. Notions of sexuality, the domestic sphere, love and romance are widened to include the folk and oral ways of expression that form part of women's creative output.

In our selection of stories and writers, we have tried to focus on the lesserpublicized, but major, contributions to literatures in the languages from which the pieces have been translated, as well as writings that speak to and address some of the issues of representation that feminist literary criticism has been trying to grapple with. Sexual desire, romance, and the sexual positioning of women are perhaps best fore-grounded through literature, as our short stories 
will show us. The short story 'In search of the shore' by Benju Sharma is a record of a woman's longing and sense of betrayal as she copes with the absences of her married lover, but also shows us how she can break out of the 'enclosed courtyard' of this relationship. In 'Yellow is the colour of longing', K.R. Meera draws a deep parallel between illness and love. It is a very oblique rendering of the state of 'being in love' - it is like an illness, but love itself provides the recuperative powers. The metaphor of jaundice and fever brings into play Indian realities, where infectious and communicable diseases constantly interrupt the tenor of everyday existence. Shaheen Akhtar's 'The make-up box' points to social inequities, where even in death, a woman who has been working in the sex trade cannot hope for a burial. It draws on sisterly love, and as the make-up man and the sister seek to bury the dead girl, a companionship bound by grief and marginality is created.

The poems by Manjuli Kanchuli blend traditional imagery with new realities. The past and the present are blended with images like 'Meera's glass' and the 'suit counter suit' that present-day betrayals can bring against each other.

The stories and poems are from writers based in Nepal, India and Bangladesh. Together they weave a South Asian mosaic, as it is difficult to tell which part of the region these writings emanate from. This volume includes translated versions as the pieces are all written in the languages of the region - Nepali, Malayalam and Bengali. We would like to draw attention to the issue of translation that transnational feminism has to grapple with, as we struggle to communicate along linguistic boundaries and differences. How faithful does one have to be to the original? What is lost in translation, but equally, how does the work resonate in another language? As we read a Nepali poem in Bangladesh, perhaps the metaphors acquire a different significance. Translations and cross-border publications are indeed useful in the case of women's writing, providing us with another way of looking at the resonance and significance of such writing.

We hope that this collection of essays, fiction and poetry captures some of the new feminist thinking emerging out of a very diverse region. The rapidly changing political and economic scenario has brought about huge transformations in which everyday lives are reconceptualized, reconstructed and lived, with new negotiations continually made between the personal and the public.

We cannot conclude without noting the cross-border solidarities and conversations defying dominant trends of nationalist politics that are a significant feature of feminist activism and scholarship in South Asia. It is appropriate, we feel, to close with these lines of poetry in Hindustani from Indian feminist Kamla Bhasin:

Main sarhad pe khadi diwaar nahin, Us deewar pe padi daraar hoon. 
I am not the wall that stands at the border,

I am the fissure in that wall.

\section{Firdous Azim, Nivedita Menon and Dina M. Siddiqi}

\section{author biographies}

Firdous Azim is Professor of English at BRAC University in Dhaka, Bangladesh. She has published widely on literary, cultural and women's issues both inside and outside the country. Her critical writings include The Colonial Rise of the Novel (1993), as well as contributions on post-colonial and women's writings in journals and edited anthologies. She is an active member of Naripokkho, a woman's activist group in Bangladesh. At the moment, she is part of an international research project entitled 'Pathways of Women's Empowerment'. She is looking at the cultural factors - specifically religion and the media - that help to construct the image of the contemporary woman.

Nivedita Menon is Professor in Political Thought at the School of International Studies, Jawaharlal Nehru University. She is the author of Recovering Subversion: Feminist Politics Beyond the Law (2004). Her more recent books are an edited volume Sexualities (2007) and Power and Contestation: India after 1989 (cowritten with Aditya Nigam). Her articles and books generally engage with contemporary history through a feminist lens.

Dina M. Siddiqi has a PhD in anthropology from the University of Michigan, Ann Arbor. She is a research consultant and a part time professor of anthropology and gender studies. Siddiqi has worked for leading human rights organizations in Bangladesh and has taught at Columbia University, the University of Pennsylvania and Bryn Mawr College, among other places. Currently, she is an adjunct faculty member at the Centre for Gender, Sexuality and HIV/AIDs at the James P. Grant School of Public Health, BRAC University, Bangladesh. Siddiqi is a member of the award-winning international network, the Coalition for Sexual and Bodily Rights in Muslim Societies (CSBR). She is also a member of the Core Advisory Group of the South Asian Network of Gender Activists and Trainers (SANGAT).

\section{references}

Akhtar, S. (2007) editor, Sati Satantara (Good and Independent Women): An Anthology of Women's Writings in Bangladesh, Dhaka: Dibya Prakash.

Akhtar, S. and Bhowmik, M. (1998) editors, Zenana Mahfil, Kolkata: Stree (English translation (2008) Women in Concert: An Anthology of Bengali Muslim Women's Writing, Kolkata: Stree).

Agrawal, A. (2006) editor, Migrant Women and Work, New Delhi: Sage.

Arya, S. (2006) editor, Poverty, Gender and Migration, New Delhi: Sage. 
Bagchi, J. and Dasgupta, S. (2003) editors, The Trauma and the Triumph: Gender and Partition in Eastern India, Kolkata: Stree.

Behera, N.C. (2006) editor, Gender, Conflict and Migration, New Delhi: Sage.

Butalia, U. (2000) The Other Side of Silence. Voices from the Partition of India, London: C Hurst \& Co.

de Alwis, M. (2002) 'The changing role of women in Sri Lankan Society' Social Research, 69(3). Available at: http://findarticles.com/p/articles/mi_m2267/is_/ai_94227137?tag=artBody;coll.

de Alwis, M. and Jayawardena, K. (1998) editors, Embodied Violence. Communalising Women's Sexuality in South Asia, New Delhi: Kali for Women.

de Mel, N. (2007) Militarizing Sri Lanka. Popular Culture, Memory and Narrative in the Armed Conflict, New Delhi: Sage.

Hussain, N., Mumtaz, S. and Saigol, R. (1997) editors, Engendering the Nation-state, Lahore: Simorgh Publications.

Ibrahim, N. (1998) Ami Birangana Bolchi (The Voices of War Heroines), Dhaka: Jagrata Prakashini.

Jayawardena, K. (1986) Feminism and Nationalism in the Third World, London: Zed Books.

Jeganathan, P. and Ismail, P. (1995) editors, Unmaking the Nation. The Politics of Identity and History in Modern Sri Lanka, Colombo: Social Scientists Association.

Kabeer, N. (2000) The Power to Choose Bangladeshi Women and Labour Market Decisions in London and Dhaka, London: Verso.

Kannabiran, K. (2005) editor, The Violence of Normal Times, New Delhi: Women Unlimited.

Khan, N., Saigol, R. and Afiya Shehrbano, Z. (1994) Locating the Self-Perspectives on Women and Multiple Identities, Lahore: ASR Publications.

Kumar, R. (1993) The History of Doing, New Delhi: Kali for Women.

Mani, L. (1989) 'Contentious traditions: the debate on sati in colonial India' in Sangari, K. and Vaid, S. (1989) editors, Recasting Women, New Delhi: Kali for Women.

Menon, R. and Bhasin, K. (1998) Borders \& Boundaries: Women in India's Partition, Eddison, NJ: Rutgers University Press.

Mohsin, A. (1997) The Politics of Nationalism: The Case of the Chittagong Hill Tracts, Dhaka: University Press Limited.

Palriwala, R. (2008) editor, Marriage, Migration and Gender, New Delhi: Sage.

Rege, S. (2006) Writing Caste/Writing Gender: Narrating Dalit Women's Testimonios, New Delhi: Zubaan.

Sarkar, T. and Butalia, U. (1995) editors, Women and the Hindu Right, New Delhi: Kali for Women.

Siddiqui, T. (2003) Transcending Boundaries: Temporary Labour Migration of Women from Bangladesh, Dhaka: University Press Limited.

Thapa, M. (2005) Forget Kathmandu. An Elegy for Democracy, New Delhi: Viking-Penguin Books India.

Thapan, M. (2005) editor, Transnational Migration and the Politics of Identity, New Delhi: Sage.

Tharu, S. and Lalitha, K. (1993) editor, Women Writing in India: 600 B.C. to the Present, in 2 Volumes, New York: The Feminist Press.

doi:10.1057/fr.2008.54 